\title{
AMBLYOMMA TICKS FOUND ON CATTLE IN THE NORTHWEST OF ARGENTINA
}

\author{
Preliminary Report ${ }^{1}$
}

\author{
A. A. GUGLIELMONE* and A. HADANI**
}

\begin{abstract}
SUMMARY. The phytogeographical and seasonal distributions of three species of Amblyomma ticks found on cattle are presented. The material studied was collected during a four-year survey in the Northwest of Argentina. Amblyomma neumanni shows predilection for the Chaqueno Serrano district although it was also found in ecotones (phytogeographical transition zones) of the adjacent Western Chaqueno district and the province of Las Yungas. Amblyomma cajennense was found in the Western Chaqueno and Chaqueno Serrano districts as well as in the province of Las Yungas. Amblyomma parvum was found in all the Western Chaqueno district and in the northern driest part of the Chaqueno Serrano district. Amblyomma neumanni seems to be inactive in summer while $A$. parvum adults predominate in summer and disappear in winter. The scarcity of the preimaginal stages of $A$. parvum on cattle suggests that these stages prefer non-bovine hosts.
\end{abstract}

\section{Les tiques du genre Amblyomma trouvées sur les bovins dans le Nord-Ouest de l'Argentine. - Rapport préliminaire.}

RÉSUMÉ. Les distributions phytogéographiques et saisonnières de trois espèces de tiques de genre Amblyomma rencontrées sur les bovins sont décrites. Le matériel a été récolté au cours d'une étude de quatre ans réalisée dans le Nord-Ouest de l'Argentine. Amblyomma neumanni a surtout été observée dans le district du Chaco Serrano, mais a été également trouvée dans les zones phytogeographiques de transition (ecotones) limitrophes du district du Chaco de l'Ouest, ainsi que dans la province de Las Yungas. A. cajennense a été trouvée dans le district du Chaco de l'ouest et dans celui du Chaco Serrano, ainsi que dans la province de Las Yungas. A. parvum a été trouvée dans tout le district du Chaco de l'ouest et dans la partie la plus sèche du district du Chaco Serrano.

$A$. neumanni semble inactive en été, alors que $A$. parvum à l'état adulte prédomine en été et disparaît en hiver. La rareté des stades pré-imaginaux de $A$. parvum sur les bovins permet de penser que ces stades préfèrent des hôtes autres que les bovins.

* Med. Vet., E.E.R.A. INTA, CC 228, 4400 Salta, Argentina.

** Parasitologist, UNDP/FAO-INTA Project ARG/75/023, CC228, 4400 Salta, Argentina.

(I) Carried out as part of the UNDP/FAO-INTA project on animal Health, ARG/75/023. Accepté le 7 juillet $198 \mathrm{I}$. 


\section{Introduction}

The Northwest of Argentina covers an area of 505,600 $\mathrm{km}^{2}$ and is approximately delimited by $22^{\circ}$ and $30^{\circ}$ latitude South and $62^{\circ}$ and $68^{\circ}$ longitude West. The bovine population is about 4 million.

Various species of Amblyomma ticks have been reported from cattle in the Northwest of Argentina (Boero, 1949, 1954, 1957; Dios and Knopoff, 1934; Guglielmone and Hadani, 1980; Ivancovich; Joan, 1920, 1928; Lahille, 1927). However, their geographical distribution has hardly been analyzed in relation to the phytogeographical zones of this area. Such an analysis should provide valuable information as to the ecological requirements of the Amblyomma species studied determining their distribution in space.

The present communication describes the distribution of some Amblyomma tick species recorded from cattle in the Northwest of Argentina in relation to the phytogeographical division of this area. Some findings on the seasonal distribution of these tick species are given as well.

\section{Materials and Methods}

According to Cabrera (1976), the Northwest of Argentina consists of 3 phytogeographical dominions, namely: Andino-Patagonic, Amazonic and Chaqueño ( fig. 1).

I - The Andino-Patagonic dominion is represented by 2 phytogeographical provinces, the Alto-Andina and the Puneña. The climate is cold and dry with an annual rainfall below $350 \mathrm{~mm}$. Frost may occur throughout the whole year and snow falls in winter. The dominant vegetation is shrubs and grasses.

II - The Amazonic dominion has one phytogeographical province, Las Yungas. The climate is hot and humid with mainly summer rainfall and frost in winter. The annual average rainfall ranges between 900 and 2,500 $\mathrm{mm}$. The dominant vegetation is tropical forest.

III - The Chaqueño dominion is represented by 2 phytogeographical provinces: 1 - The Del Monte province has a hot, dry climate with an annual rainfall of 80 $200 \mathrm{~mm}$ which falls in summer. The dominant vegetation consists of xerophylic, psammophylic and halophylic bushes.

2 - The Chaqueño province has a hot climate with mainly summer rainfall. The dominant vegetation consists of deciduous xerophylic forest. This province, which is the only part of the Northwest of Argentina where cattle breeding assumes importance, has 2 phytogeographical districts:

a) The Chaqueño Serrano district is characterized by a dominant vegetation of xerophylic forest largely composed of Schinopsis hankaena and patches of hard grasses. The mainly summer rainfall is $400-800 \mathrm{~mm}$, annually. 


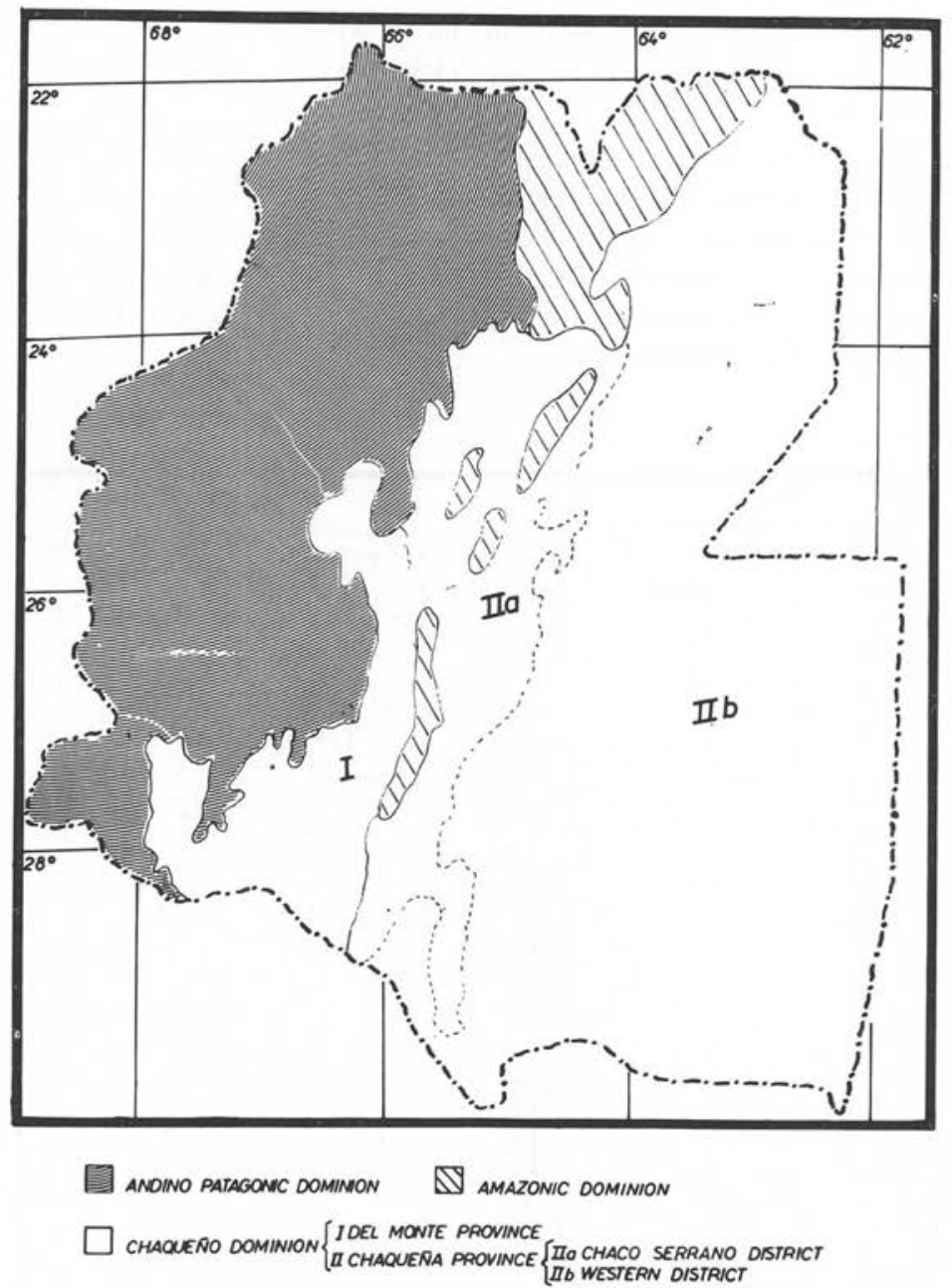

FIG. I. - Phytogeographical division of the northwest of Argentina (Compiled from Ragonese, I967 and Cabrera, I976)

b) The Western Chaqueño district has an annual rainfall of 500-800 mm. The vegetation consists of xerophylic forest. The climax plant society is formed by Schinopsis lorentzii and Aspidosperma quebracho blanco. The structure of this plant society has been changed by cattle grazing and forest exploitation (Morello y Saravia Toledo, 1959).

Ticks were frequently collected from cattle in the study area, by the authors and field veterinarians during the period of July 1976 - June 1980. These tick 
collections were carried out irregularly during all seasons of the year. Each sample was recorded by number and species of ticks, stage of development, geographical location and date of collection.

Adult ticks were classified according to the keys of Jones et al. (1972) and Guglielmone and Hadani (in preparation). Nymphs were identified according to a key based on the authors' unpublished data. Engorged larvae were allowed to moult into nymphs and identified by the same key used for nymphal identification. Previous findings of Amblyomma tick species in the area studied recorded in the literature were included as well.

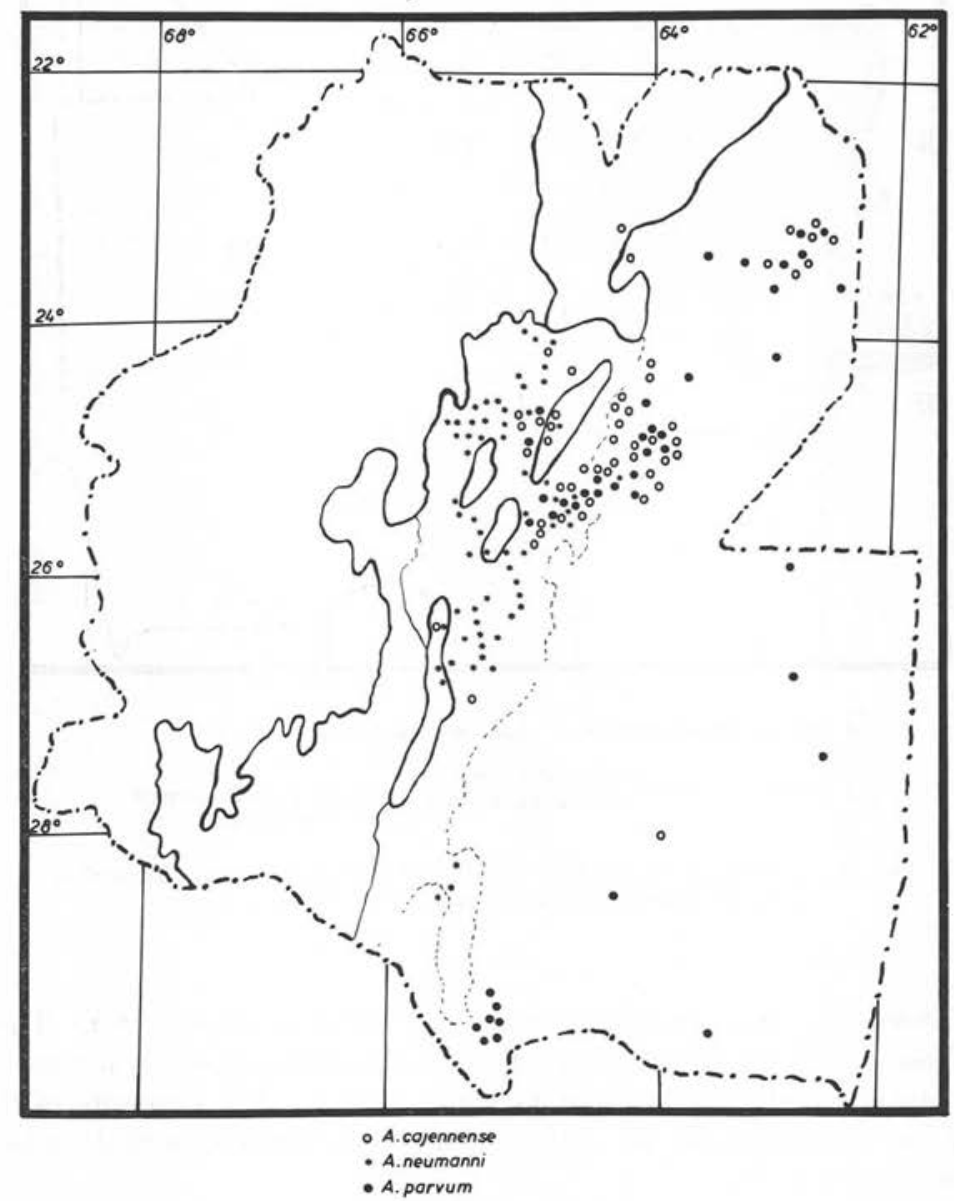

FIG. 2. - Distribution of amblyomma tick species on bovines in the northwest of Argentina (Compiled from various sources and authors' findings) 


\section{Results and Discussion}

The phytogeographical distribution of Amblyomma tick species based on the authors' findings and on previous reports is shown in figure 2.

Amblyomma neumanni shows a marked predilection for the Chaqueño Serrano district. The findings of Joan $(1920,1928)$ and of Boero (1957) of A. neumanni in other parts of Argeñtina indicate that the predilection for the Chaqueño Serrano district also occurs beyond the Northwest. Only a few findings were reported from outside the Chaqueño Serrano district. These were all located in the transition zones (ecatones) between that district and the neighbouring areas such as the Western Chaqueño district and the province of Las Yungas.

Amblyomma parvum has been found only in the Chaqueño province (Guglielmone and Hadani, 1980). This tick species is present in both districts of this province but in the Chaco Serrano district it is restricted to the northern drier part. The predilection of $A$. parvum for dry areas had also been mentioned by Fairchild (1966) and Guglielmone and Hadani (1980).

Amblyomma cajennense has been found in both districts of the Chaqueño province as well as in the province of Las Yungas. Boero $(1949,1954)$ and Ringuelet (1948) reported finding $A$. cajennense south of $26^{\circ}$ latitude South but this could not be confirmed by the present authors.

Amblyomma cajennense has been reported by various authors (Boero, 1949, 1954; Fairchild et al., 1966; Jones et al., 1972; Lahille, 1927; Prieto, 1974; Ringuelet, 1948; Smith, 1975; Varma, 1973) from widely different biotopes both in Argentina and in other countries, which indicates the versatility of A. cajennense ticks and their adaptability to a wide variety of ecological zones.

TABLE I. - Seasonal distribution of amblyomma tick species collected from bovines in the northwest of Argentina.

\begin{tabular}{|c|c|c|c|c|c|}
\hline & & Summer & Autumn & Winter & Spring \\
\hline ष. & $\begin{array}{l}\text { Adults } \\
\text { Nymphs } \\
\text { Larvae }\end{array}$ & $\begin{array}{r}3797 \\
0 \\
0\end{array}$ & $\begin{array}{r}542 \\
3 \\
5\end{array}$ & $\begin{array}{l}78 \\
92 \\
20\end{array}$ & $\begin{array}{r}185 \\
159 \\
0\end{array}$ \\
\hline 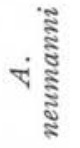 & $\begin{array}{l}\text { Adults } \\
\text { Nymphs } \\
\text { Larvae }\end{array}$ & $\begin{array}{l}4 \\
0 \\
0\end{array}$ & $\begin{array}{r}1295 \\
22 \\
199\end{array}$ & $\begin{array}{r}2090 \\
240 \\
27\end{array}$ & $\begin{array}{r}919 \\
210 \\
0\end{array}$ \\
\hline षं ฐँ & $\begin{array}{l}\text { Adults } \\
\text { Nymphs } \\
\text { Larvae }\end{array}$ & $\begin{array}{r}823 \\
0 \\
0\end{array}$ & $\begin{array}{r}87 \\
0 \\
0\end{array}$ & $\begin{array}{l}1 \\
4 \\
0\end{array}$ & $\begin{array}{r}325 \\
0 \\
0\end{array}$ \\
\hline
\end{tabular}


Boero (1957) recorded $A$. parvitarsum on cattle in the Andino-Patagonic dominion. This species was not found in the present study.

The seasonal distribution of larvae, nymphs and adults of the 3 species of Amblyomma found on cattle is summarized in Table $I$.

Adults of $A$. cajennense were found throughout the year although in greater numbers in summer. Larvae and nymphs were found only in the dry season which agrees with reports of Aragao (1936) and Fairchild (1966).

All stages of $A$. neumanni were found during autumn and winter. In the spring no larvae could be found. Very few $A$. neumanni ticks were found in summer, indicating that this tick species is inactive during this season. A. parvum adults were commonest in summer and almost completely disappeared in winter. The seasonal behaviour of both species deserves further study, and might provide information with regard to the number of generations/year ratio.

The scarcity of preimaginal stages of $A$. parvum on cattle suggests that this ill-known species prefers non-bovine hosts.

AcKNowledgements The authors gratefully acknowledge the assistance of the staff members of UNDP/FAO - INTA Project ARG/75/023 and Drs. A. Abeya., J. Chiaraviglio, H. Grossberger, D. Malandrini, J. Nogues, G. Poodts and E. Salem.

\section{RÉFÉRENCES}

Aragão H. de B. : Ixodidas brasilieros e de alguns paizes limitrophes. Mem. Inst. O. Cruz, 1936, $3 I, 759-844$.

Bozro J. J. : Los ixodideos de la Republica Argentina, I949.

Boero J. J. : Los ixodideos de la Republica Argentina y su huespedes. Rev. Fac. Agr. Vet. (Buenos Aires), 1954, 139, 505-514.

Boero J. J. : Las garrapatas de la Republica Argentina (Acarina - Ixodoïdea) I33 p., Universidad de Buenos Aires, Departamento Editorial, Buenos Aires, 1957.

CABrera A. L. : Enciclopedia Argentina de Agricultura y Ganaderia. Fascicul I. Regiones fitogeograficas argentinas. 2a Ed. Tomo III, 85 p. Editorial ACME, Buenos Aires, 1976.

Dios R. L., Knopoff R. : Sobre Ixodoïdea de la Republica Argentina. Rev. Inst. Bact. Depto. Nac. Hig., 1934, 6, 359-412.

Fairchild G. B., Kohls G. M., Tipton V. J. : The ticks of Panama (Acarina: Ixodoïdea). In: Ectoparasites of Panama (Editors: R. L. Wenzel and V. J. Tipton), pp. 167-219, Field Museum of Natural History, Chicago, I966.

Guglielmone A. A., Hadani A. : Hallazgos de Amblyomma parvum Aragão, r9o8 en Catamarca y Salta. Rev. Med. Vet. (Buenos Aires), I980, 61, 121-129.

Guglielmone A. A., Hadani A. : Amblyomma neumanni Ribaga, I902: Su nomenclatura y taxonomia (in preparation).

IVANCOVICH J. C., personal communication.

JoAn, TERESA : Sobre el genero Amblyomma y dos de sus especies en la Argentina, 20 p., Min. A gric. Nac. Dirección Lab. Investi. Agric. Gan. Buenos Aires, I920.

JoAn, Teresa : Nota sobre el Amblyomma neumanni, A. testudinis $y$ A. auriculare, pp. 665-667, 4a Reunion Soc. Arg. Pat. Reg. Norte, Santiago del Estero, 7-9 Mayo, 1928. 
Jones E. K., Clifford C. N., Keirans J. E., Kohls G. M. : The ticks of Venezuela (Acarina: Ixodoïdea) with a key to the species of Amblyomma in the Western Hemisphere, 40 p., Brigham Young Univ. Sci. Bull., Biological Series, $17,1972$.

Lahille F. : Nota sobre algunos acaros del pais, pp. 662-68o, za Reunion Soc. Arg. Pat. Reg. Norte, Tucuman, 7-ro Mayo, 1927.

Morello J., Saravia Toledo C. : El bosque chaqueño. I. Paisaje primitovo, paisaje natural y paisaje cultural en el oriente de Salta. Rev. A gr. No A, I959, 3, 5-81.

Prieto R. : Distribucion geografica, influencia ecologica y selectividad hospedera de Amblyomma cajennense (Fabricius, I 787) en Cuba. Rev. Cub. Cienc. Vet., I974, 5, 47-51.

RAgonese R. : Vegetacion y ganaderia en la Republica Argentina, 2 I 8 p., Coleccion Cientifica del INTA. Buenos Aires, I967.

RINGUELET R. : Zooparasitos de interes veterinario, su distribucion en la Argentina segun comprobaciones de la Direccion de Patologia Animal 1935 - 1945, 54 p., Ministerio de agricultura de la Nacion. Publicacion Miscelanea (28I). Buenos Aires, 1948.

Sмrтн M. W. : Some aspects of the ecology and life cycle of Amblyomma cajennense (Fabricius I787) in Trinidad and their influence on tick control measures. Ann. Trop. Med. Parasit., $1975,69,121-129$.

VArma M. G. R. : Ticks (Ixodidae) of British Honduras. Trans. R. Soc. Trop. Med. Hyg., I973, $67,92-102$. 